\title{
EFEKTIVITAS PENDEKATAN KETERAMPILAN PROSES BERMAIN DALAM PEMBELAJARAN PENDIDIKAN JASMANI BERBASIS LESSON STUDY UNTUK MENINGKATKAN PENGEMBANGAN KEMAMPUAN JASMANI SISWA
}

\author{
I Wayan Darsana1, MGR Kristiantari², IB.G. Surya Abadi ${ }^{3}$, dan I Wayan Wiarta ${ }^{4}$ \\ 1,2,3,4Jurusan Pendidikan Guru Sekolah Dasar, FIP \\ Universitas Pendidikan Ganesha \\ Singaraja, Indonesia \\ e-mail: wydarsana01@gmail.com
}

\begin{abstract}
Abstrak
Penelitian ini bertujuan untuk meningkatkan kemampuan dasar gerak, gerak dasar, dan kemampuan gerak keterampilan melalui penerapan pendekatan keterampilan proses bermain dalam pembelajaran pendidikan jasmani berbasis lesson study. Subyek penelitian yang digunakan siswa kelas IV berjumlah 36 orang, terdiri dari 24 orang siswa putra dan 12 orang siswa putri pada SD Negeri 2 Sesetan Denpasar Selatan Kota Denpasar. Metode penelitian yang digunakan adalah jenis penelitian berbasis lesson study yang telah dirancang dalam siklus. Pengumpulan data dengan teknik observasi dan data dianalisis menggunakan teknik analisis deskriptif dengan persentase dan deskriptif kualitatif. Hasil penelitian menunjukkan bahwa dengan pendekatan keterampilan proses bermain dalam pembelajaran pendidikan jasmani olahraga dan kesehatan pada siswa sekolah dasar ada kecenderungan naik atau meningkat secara berkelanjutan dari skor pra-siklus, siklus 1 dan siklus 2. Hal ini didasarkan pada pencatatan kegiatan sebelum tindakan (Pra-siklus) diperoleh nilai rata-rata 16.39 dengan ketuntasan mencapai $38.9 \%$, selanjutnya hasil analisis siklus 1 menunjukkan nilai rata-rata naik menjadi 17.50 dengan ketuntasan mencapai $52.8 \%$, demikian pula pada siklus 2 nilai rata-rata naik menjadi 20.69 dengan ketuntasan mencapai $97.2 \%$. Hal ini berarti effektivitas pendekatan keterampilan proses bermain dalam pembelajaran pendidikan jasmani berbasis lesson study secara berkelanjutan mengalami peningkatan dengan menitik beratkan pada latihan gerak yang sifatnya informal dan bebas sesuai dengan tujuan pendidikan di sekolah dasar yang mengembangkan seluruh aspek perkembangan siswa, maka yang dilakukan adalah mengembangkan jasmani siswa bukan mengajarkan olahraga, siswa diberikan bergerak didalam bermain agar mampu menggunakan otot-otot besar maupun otot-otot kecil dengan baik dalam melakukan gerakan-gerakanya.
\end{abstract}

Kata-kata kunci : Pengembangan Kemampuan Jasmani (PKJ)

\begin{abstract}
The purpose of this research for develop the basic motion ability and motion skills by using approach application in playing skill process in physical education learning based on lesson study. The subject of this research were the students from IV grade that have 36 students, that consist of 24 male students and 12 female students in SD Negeri 2 Sesetan Denpasar Selatan Kota Denpasar. The types of research method that uses lesson study that already arrangement by using cycles. The collections of data in this research was using observation techniques and analysis data by uses descriptive analysis techniques by percentage and descriptive qualitative. The result of this research find that the using in playing skill process approach in physical sport and healthy education learning for the students of elementary school has increased tendency or continued development from pre-cycles, $1^{\text {st }}$ cycles, and $2^{\text {nd }}$ cycles. That was based on registration activities before the action (Pre-cycles) that get in average scores 16, 39
\end{abstract}


with passed percentage $38.9 \%$, after that the result analysis in $1^{\text {st }}$ cycles show that the average scores increased become 17,50 with passed percentage $52,8 \%$, based on that in $2^{\text {nd }}$ cycles, average scores increased become 20,69 with passed percentage $97,2 \%$. It means that the effective approach in playing skill process in physical education learning based on lesson study by continued had increasing with emphasize from the motion practice that is informal and free based on the education purpose in elementary school to developed all aspect in student's development, then that must did is developed the student's physical not thought sport, students gave motion in the playing activity to be able to used the big muscles and the small muscles very well for did their motion.

Keywords: Developing of Physical Ability (PJK)

\section{Pendahuluan}

Dewasa ini pengembangan kurikulum yang bersifat sentralistik sudah tidak bisa dipertahankan lagi. Standar yang sama untuk semua sekolah di seluruh wilayah tanah air tidak dapat digunakan lagi karena hasilnya menunjukkan adanya perbedaan yang sangat signifikan. Dengan diberlakukannya kurikulum 2013 yang diharapkan dalam pelaksanaannya secara terintegrasi dengan mata pelajaran yang lainnya, namun setelah berjalan beberapa tahun masih mengalami beberapa kendala di lapangan.

Dengan diberlakukannya otonomi daerah, daerah diberi keleluasaan dalam mengembangkan pendidikan yang merupakan upaya untuk meningkatkan kualitas sumber daya manusia. Para guru pendidikan jasmani, olahraga dan kesehatan mempunyai otonomi mempergunakan keadaan ini sebaikbaiknya membangun kreativitas, daya cipta dan keterlibatan guru dalam berbagai kegiatan inovatif yang bersifat pengembangan menuntun ke arah tertentu yang dapat dipertanggung jawabkan penuh, mengarang sendiri maupun memodifikasi beberapa model latihan yang ternyata menyenangkan muridmurid, akan jauh lebih bermakna dalam mengajar dengan penuh kegembiraan. Keluhan tentang rendahnya kemampuan dasar gerak siswa di tingkat sekolah dasar masih sering terdengar khususnya dalam memahami materi pelajaran pendidikan jasmani olahraga dan kesehatan. Hal ini akibat dari rendahnya kualitas proses pembelajaran yang dilaksanakan oleh guru dan siswa di sekolah, dalam temuan pelaksanaan penelitian tindakan kelas (Darsana, 2008),

Dengan demikian upaya yang dapat dilaksanakan guru pendidikan jasmani olahraga dan kesehatan di lapangan adalah mengimplementasikan materi pembelajaran Pengembangan Kemampuan Jasmani (PKJ) dan Olahraga. Guru sebagai fasilitator dan juga menguasai metoda dan strategi mengajar untuk menggugah minat siswa terhadap pembelajaran pendidikan jasmani olahraga dan kesehatan. Guru yang kreatif dan inovatif mampu menciptakan suasana kelas menjadi aktif, menyenangkan, dan menggembirakan dalam menangani pembelajaran guna meningkatkan kemampuan gerak motorik siswa. Salah satu faktor yang mempengaruhi kualitas fisik manusia dalam batas-batas penelitian ini yang diteliti berkaitan dengan pengembangan kemampuan jasmani yang dibicarakan adalah dasar gerak, gerak dasar, dan gerak keterampilan. Berdasarkan permasalahan di atas maka bagaimanakah pendekatan keterampilan proses bermain dalam pembelajaran pendidikan jasmani berbasis lesson study meningkatkan kemampuan dasar gerak, gerak dasar dan gerak keterampilan siswa kelas IV SD Negeri 2 Sesetan Denpasar Selatan?

Sekolah dasar adalah merupakan tempat bagi anak-anak untuk mengembangkan diri, baik dari segi fisik, mental maupun sosial. Pendidikan jasmani, olahraga dan kesehatan adalah suatu bagian dari pendidikan secara keseluruhan yang mengutamakan aktivitas jasmani dan pembinaan hidup sehat untuk pertumbuhan dan pengembangan aspek fisik, mental dan sosial secara serasi, selaras, dan seimbang (Depdikbud, 1993)

Hal ini diperkuat oleh pendapat Corbin, yang menyatakan bahwa satu bagian terpenting dari pengembangan diri anak, khususnya perkembangan motorik adalah kebugaran jasmani (Physical Fitness). Demikian pula Clark (1976) mendefinisikan kebugaran jasmani sebagai kemampuan untuk melakukan tugas sehari-hari dengan giat tanpa mengalami kelelahan, dan masih memiliki sisa energi untuk menikmati waktu luang, serta menghadapi hal-hal yang tak terduga sebelumnya. Kebugaran jasmani menurut Corbin (1980 : 101) adalah efektivitas fungsi dalam kehidupan sehari-hari tanpa mengalami kelelahan, dan masih memiliki cadangan energi untuk menikmati waktu luangnya. Senada dengan itu, Gabbard, dkk (1987: 2) mengartikan kebugaran sebuah konsep tentang kemampuan fungsi tubuh secara normal tanpa mengalami kelelahan dan masih mampu menikmati waktu luang tanpa 
mengalami beban fisik secara berlebihan. Selanjutnya Mangi, Richard, dkk (1987:11) menyatakan bahwa kata kebugaran jasmani menunjukkan keadaan yang berbeda-beda pada setiap orang, secara fisiologis, kebugaran jasmani merupakan kemampuan untuk melakukan kerja dengan usaha minimal.

Dapat disimpulkan bahwa para siswa dapat menyesuaikan tugasnya dengan baik tanpa merasa kelelahan yang berarti, kebugaran jasmani bagi setiap individu sangatlah penting. Dengan demikian untuk dapat melakukan pekerjaan yang efisien tanpa menimbulkan kelelahan yang berarti, maka pengembangan kemampuan jasmani dan olahraga perlu mendapatkan penanganan sejak dini dengan baik.

Pengembangan jasmani, adalah suatu proses kegiatan seseorang yang menghasilkan alat atau cara yang baru di dalam mempelajari gerakan melalui langkah-langkah perencanaan, pelaksanaan, dan penyempurnaan berdasarkan penilaian yang dilakukan secara terus-menerus selama kegiatan itu berlangsung. Sedangkan kemampuan jasmani adalah kesanggupan seseorang yang menggerakkan anggota badan di dalam mempelajari gerakan, hingga memiliki rangkaian urutan gerak yang teratur, luwes, cepat, tepat, dan lancar melalui latihan yang teratur dan terus-menerus.

Pengembangan jasmani pada anak-anak sekolah dasar menitik beratkan pada latihan gerak yang sifatnya informal dan bebas sehingga anak dapat menguasai dasar gerak, gerak dasar, dan gerak keterampilan yang diperlukan untuk pertumbuhan dan perkembangan diri selanjutnya dalam menggunakan gerakan-gerakan anggota badannya hingga menghasilkan gerakan baru melalui belajar dan latihan. Mereka dilatih agar mampu menggunakan otot-otot besar maupun otot-otot kecil dengan baik agar mereka lebih tangkas di dalam gerakan-gerakannya

Rudolf Laban ( 1930 ) seorang ahli yang mengemukakan bahwa gerakan yang diajarkan pada anak-anak sekolah dasar selalu berkaitan dengan hal-hal berikut, 1). Waktu, yang berkaitan dengan cepat/lambat. Misalnya, gerakan yang dilakukan oleh seluruh atau sebagian tubuh dengan kecepatan yang berbeda mulai dari yang cepat sampai yang lambat atau dari yang lambat sampai yang cepat. Gerakan dapat dipercepat atau diperlambat dan gerakan dapat berirama, 2). Beban, gerakan dapat diberikan dalam bentuk gerakan yang berat, ringan atau sedang, 3). Ruang, gerakan juga berkaitan dengan ruang, yaitu sejauh mana gerakan tubuh itu menggunakan ruang dalam pelaksanaannya. Tubuh atau sebagian tubuh dapat digerakan ke berbagai arah. Mislnya, maju ke depan, mundur ke belakang, malangkah ke samping, dan bisa juga bergerak melalui jalur tertentu, seperti lurus langsung atau memutar. Anak juga bergerak dalam level yang berbeda. Misalnya, dalam ketinggian tertentu, 4). Alur, gerakan adalah sesuatu yang berkesinambungan yang mengalir dari suatu gerak tertentu ke gerak lainnya. Gerakan juga merupakan suatu kesatuan yang mempunyai alur yang indah, yang meliputi dari gerakan seluruh tubuh, gerakan beberapa bagian tubuh atau yang berkaitan dengan orang atau pun objek lainnya.

Aspek kualitatif dari gerakan yang ditampilkan oleh anak, menurut Laban tergantung pada usaha, yaitu bagaimana seseorang mengkombinasikan penggunaan berbagai unsur/faktor tersebut ( waktu, beban, ruang, dan alur ). Oleh karena itu, ide atau tema gerakan sangatlah esensial. Artinya di dalam mengajarkan gerakan pada anak, seorang guru muncul mempunyai ide ( gagasan ) berupa gerakan apa saja yang akan dimunculkan dan bagaimana caranya, misalnya kegiatan drama, tarian, senam atau melalui berbagai permainan ( games ) yang disesuaikan dengan karakteristrik anak didik.

Selain itu lain Adams dan B.E. Rahantoknam mengemukakan, bahwa keterampilan pengelolaan tubuh dasar yang diajarkan pada kelas-kelas permulaan di sekolah dasar (dalam kurikulum SD Bidang Studi Pendidikan Jasmani Olahraga dan Kesehatan) diberikan mulai dari kelas I s/d IV, terdiri atas (a) Keterampilan lokomotor, (b) Keterampilan non-lokomotor, dan (c) Keterampilan manipulasi.

Pengembangan Kemampuan Jasmani untuk di sekolah dasar juga harus bersumber pada unsur dasar gerak, gerak dasar, gerak keterampilan, dan olahraga. Gerakan-gerakan yang harus dikembangkan dan diasah pada usia sekolah dasar adalah sebagai berikut : Dasar Gerak, adalah gerakan-gerakan dasar yang berkembang sejalan dengan tingkat pertumbuhan dan tingkat perkembangan usia seseorang, demikian pula menurut Syarifuddin dan Yusuf (1996) menerangkan bahwa dasar gerak merupakan gerak pengulangan yang dilakukan terus menerus dari kebiasaan serta menjadikannya sebagai dasar dari pengalaman ligkungan mereka. Dasar gerak yang identik dengan kebugaran jasmani meliputi unsur-unsur kebugaran, yakni : (1) kekuatan/strength, (2) kecepatan, (3) kelincahan, (4) kelentukkan, (5) ketepatan, (6) daya tahan, (7) keseimbangan, (8) koordinasi , (9) konsentrasi. Gerak Dasar, merupakan gerak pengulangan yang dilakukan terus-menerus dari kebiasaan serta menjadikannya sebagai dasar dari pengalaman lingkungan mereka meliputi gerak jalan, lari, lempar, lompat. Gerak dasar fundamental (fundamental basic movement) menurut Harrow (1972) adalah pola gerak yang membentuk dasar-dasar untuk keterampilan gerak yang kompleks, yang meliputi (1) gerak lokomotor (2) gerak non lokomotor, dan (3) gerak manipulatif Gerak lokomotor yang meliputi gerak 
tubuh yang berpindah tempat, berpindahnya individu dari satu tempat ke tempat yang lain seperti berjalan, berlari, melompat, meluncur, berguling, dan bersepeda. Contoh gerak lokomotor. a). dasar menggunakan 1 elemen ( kaki ) seperti jalan, lari, lompat, loncat, b). kombinasi menggunakan 2 elemen atau lebih ( tangan, kaki, indra ), seperti memanjat, meluncur, menderap, dan melompat-lompat. Gerak nonlokomotor, yaitu menggerakan anggota tubuh dengan posisi tubuh diam di tempat, seperti berayun, mengangkat, bergoyang, merentang, melengkung, memutar, mendorong. Keterampilan ini sering dikaitkan dengan keseimbangan atau kestabilan tubuh, yaitu gerakan yang membutuhkan keseimbangan pada taraf tertentu, seperti berputar dan mengayunkan kedua tangan di tempat. Contoh gerakan non lokomotor/ keseimbangan a). Axial, seperti membungkuk, meregang, berputar, berayun dan melekuk., b). Statis dan dinamis, seperti keseimbangan tegak, keseimbangan terbalik, berguling, memulai gerak, berhenti, mengelak dan mengapung/mengambang. Gerak manipulatif, melibatkan tindakan mengontrol suatu objek khususnya dengan tangan dan kaki. Ada dua klasifikasi dari gerak manipulatif, yaitu reseptif dan propulsif. Olahraga, Menurut Menpora (1983) bahwa : "Olahraga adalah bentuk-bentuk kegiatan jasmani yang terdapat dalam permainan, perlombaan dan kegiatan jasmani yang intensif dalam rangka memperoleh rekreasi, kemenangan dan prestasi optimal". Sedangkan menurut UNESCO bahwa : "Olahraga adalah setiap kegiatan fisik yang mengandung sifat permainan dan berisi perjuangan dengan diri sendiri atau dengan orang-orang lain, atau konfrontasi dengan unsur-unsur alam".

Tujuan ideal pendidikan jasmani dan kesehatan di sekolah dasar kurang tercapai, yang seharusnya dapat memupuk kreativitas siswa, keterampilan sosial, sikap hidup bersama dalam kemajemukan, kebugaran jasmani, dan kesehatan yang memadai.

Sebagai ilustrasi Pengembangan Kemampuan Jasmani (PKJ).

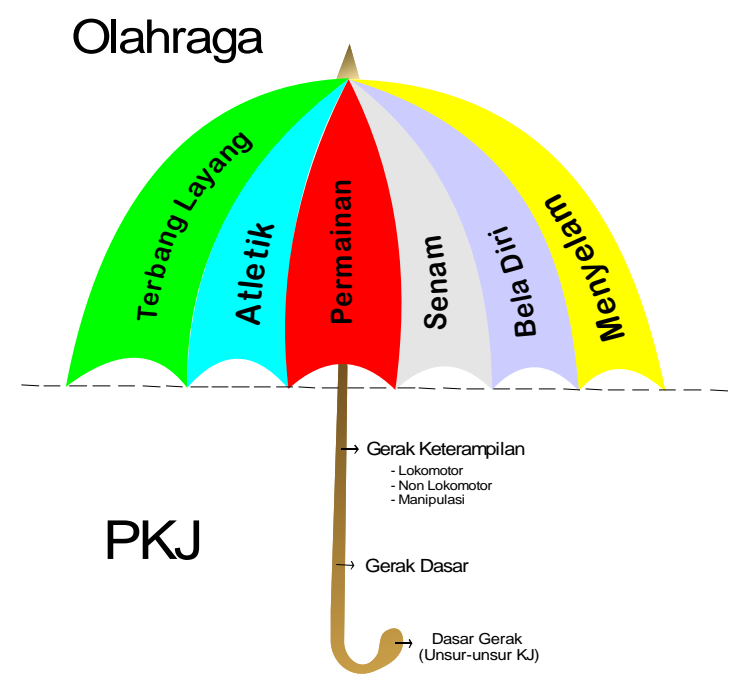

\section{Gambar 1. Pengembangan Kemampuan Jasmani dan Olahraga}

Pendampingan Berbasis Lesson Study, kegiatan pembinaan untuk meningkatkan kualitas guru dalam satu kelompok mata pelajaran maupun kelompok guru kelas, maka ditempuh model pelaksanaan melalui pendampingan/ berbasis lesson study. Cara ini dilakukan karena guru dalam satu kelompok dapat saling belajar tentang metode pembelajaran dan juga mendiskusikan proses pembelajaran yang dilakukan berdasarkan hasil pengamatan bersama saat salah seorang guru memperaktekkan rancangan pembelajaran yang disusun bersama, dan yang lebih penting guru dapat memahami bagaimana siswa belajar. 
Joharmawan (2006), mengungkapkan lesson study adalah bentuk kegiatan yang dilakukan oleh guru/ sekelompok guru yang bekerjasama dengan orang lain merancang kegiatan untuk meningkatkan mutu belajar siswa dari kegiatan pembelajaran yang dilakukan oleh salah seorang guru berdasarkan pelaksanaan pembelajaran yang dirancang bersama, kemudian diobservasi oleh teman guru lain dan selanjutnya melakukan refleksi bersama atas hasil pengamatan pembelajaran. Refleksi dimaksudkan untuk mendiskusikan dan menyempurnakan proses pembelajaran yang menitik beratkan pada kegiatan belajar siswa, bukan untuk mengkritik penampilan guru. Kegiatan belajar siswa yang difokuskan untuk diamati meliputi: bagaimana siswa belajar, perilaku siswa selama belajar, kapan siswa mulai bosan, bagaimana interaksi siswa dengan yang lainnya, dan lain-lain.

Perubahan sikap yang diperlukan oleh seorang guru dalam melaksanakan lesson study meliputi: 1). Semangat introspeksi terhadap apa yang sudah dilakukan selama melakukan proses pembelajaran, 2). Keberanian untuk membuka diri untuk dapat menerima saran dari orang lain guna peningkatan kualitas diri, 3). Keberanian untuk mengakui kesalahan diri sendiri, 4). Keberanian untuk mengakui dan memakai ide orang lain yang baik, 5). Keberanian untuk memberikan masukan yang jujur kepada orang lain. Dalam kegiatan seperti ini sangat diperlukan dalam melaksanakan K13

Lesson study merupakan siklus kegiatan kelompok guru yang bekerja sama dalam menentukan tujuan pembelajaran, melakukan research lesson, dan secara berkolaborasi mangamati, mendiskusikan dan memperbaiki pembelajajaran tersebut, ( Lewis, 2002 ).

Adapun siklus dalam lesson study seperti berikut.

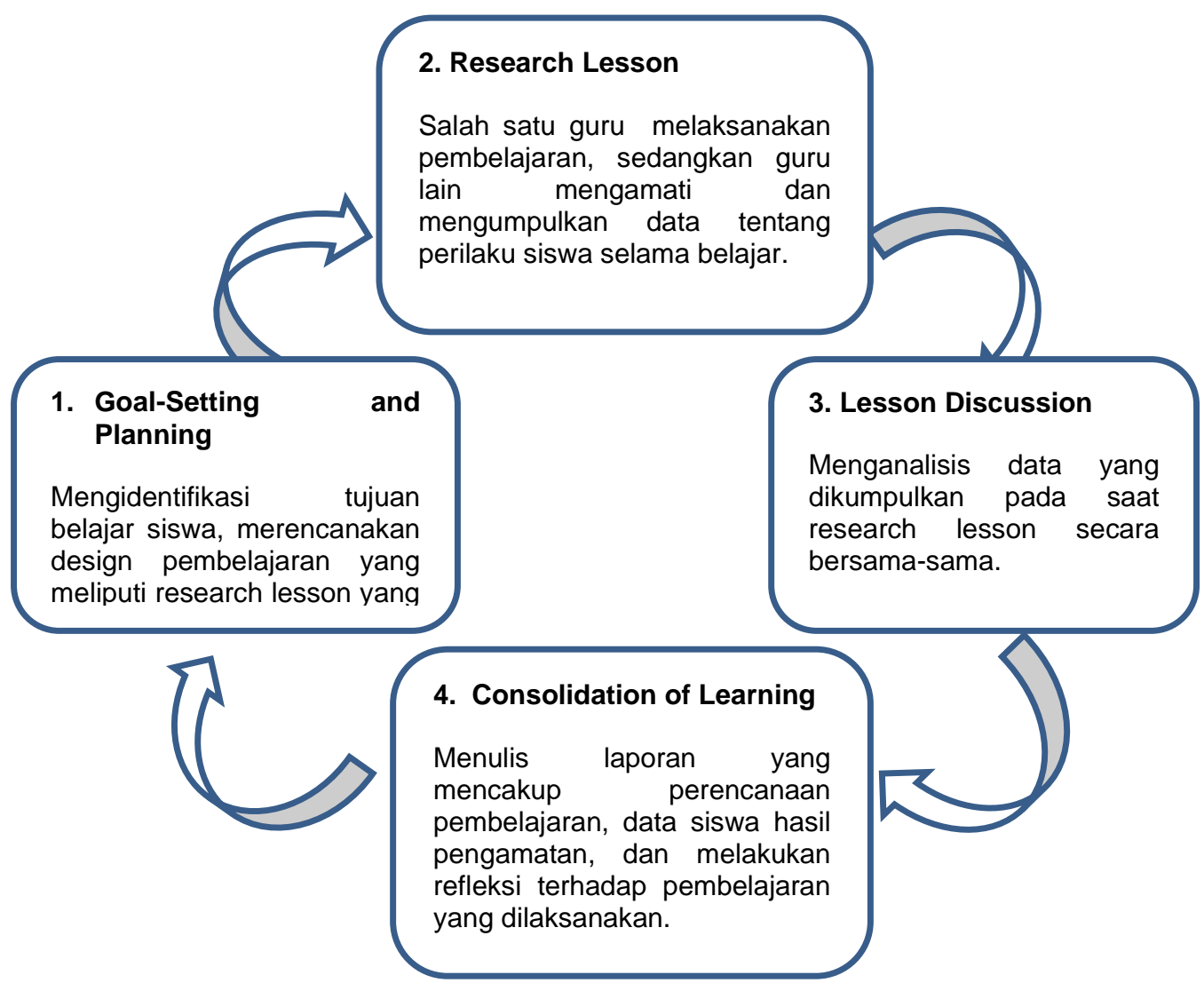

Gambar 2. Siklus Lesson Study 
Langkah-langkah pelaksanaan lesson study mencakup tujuh kegiatan, yakni: 1 . Pembentukan kelompok lesson study, 2. Penentuan focus lesson study, 3. Perencanaan lesson study, 4. Persiapan observasi, 5.pelaksanaan dan observasi pembelajaran, 6. Tanya jawab (diskusi) tentang pembelajaran yang dilaksanakan, dan 7. Refleksi dan perencanaan langkah berikutnya ( Richarson, 2004). Berdasarkan tujuh tahapan lesson study yang dipaparkan, maka secara sederhana kegiatan lesson study dapat disederhanakan menjadi kegiatan : plan, do- see dan reflection.

\section{Metode}

Yang menjadi subyek dalam penelitian ini adalah siswa kelas IV SD Negeri 2 Sesetan, Denpasar Selatan tahun ajaran 2017/2018 yang berjumlah 36 orang , terdiri dari 24 orang putra dan 12 orang putri, dari jumlah 36 orang siswa yang telah diobservasi pada hari Jumat tanggal 4 Mei 2018 dan berdasarkan analisis hasil siswa yang sudah mencapai kriteria baik 12 orang siswa ( $33.3 \%$ ), 19 orang siswa ( $52.8 \%$ ) memperoleh kriteria cukup, dan kriteria kurang 5 orang siswa ( $13.9 \%$ ). Dalam mengikuti proses pembelajaran pendidikan jasmani olahraga dan kesehatan. Selanjutnya dalam proses pembelajaran dilaksanakan menjadi lebih efektif dengan pola kooperatif kolaboratif dalam bentuk diskusi yang diakhiri dengan presentasi. Dengan adanya lesson study guru/peneliti sudah mulai mengalami pola pembelajarannya yang lebih berpusat pada aktivitas siswa. Deskripsi proses pembelajaran persiklus melalui tahapan kegiatan penyamaan persepsi dalam penyusunan RPP secara bersama dan implementasinya dilaksanakan dalam dua siklus melalui tahapan Plan, Do, dan See.

Data yang dikumpulkan dalam penelitian ini menggunakan metode observasi berstruktur disusun berdasarkan indikator dasar gerak, gerak dasar, dan gerak keterampilan. Segala kegiatan observasi telah ditetapkan berdasarkan kerangka kerja yang telah diatur kriteria penilaiannya, yaitu melakukan pengamatan langsung terhadap proses tindakan dengan mengamati keterampilan siswa pada saat proses belajar berlangsung (Agung A.A, 2004). Instrumen pengumpulan data yang digunakan berupa lembar observasi yang dijabarkan dari indikator variabel yang diteliti. Data dianalisis dengan menggunakan teknik analisis deskriptif dengan persentase dan deskriptif kualitatif. Teknik analisis deskriptif adalah suatu cara pengolahan data yang dilakukan dengan jalan menyusun secara sistematis dalam bentuk angka-angka dan atau persentase mengenai keadaan suatu objek yang diteliti sehingga diperoleh kesimpulan umum. (Agung. 2010:67)

Metode analisis deskriptif kuantitatif ini digunakan untuk menentukan tingkatan tinggi rendahnya melakukan keterampilan proses bermain dalam pembelajaran pendidikan jasmani. dan hasil yang dicapai dikonversikan kedalam kriteria penilaian.

\section{Hasil dan Pembahasan}

Berikut berturut-turut disajikan data hasil observasi pengembangan kemampuan jasmani, jumlah persentase nilai yang diperoleh masing-masing item yang diobservasi, nilai rata-rata yang diperoleh pada pra-siklus, siklus I, dan siklus II, dan persentase ketuntasan berdasarkan kriteria penilaian.

Tabel. 1. Data Hasil Observasi PKJ Siswa

\begin{tabular}{ccccccc}
\hline \multirow{2}{*}{ Pelaksanaan } & \multirow{2}{*}{ Warna } & \multicolumn{5}{c}{ Observasi/ Item } \\
\cline { 3 - 7 } & & Lari & Lompat & Lempar & Tangkap & Pukul \\
\hline Pra Siklus & Biru & 63 & 65 & 61 & 69 & 68 \\
Siklus I & Merah & 69 & 66 & 74 & 78 & 62 \\
Siklus II & Hijau & 77 & 84 & 86 & 87 & 81 \\
\hline
\end{tabular}




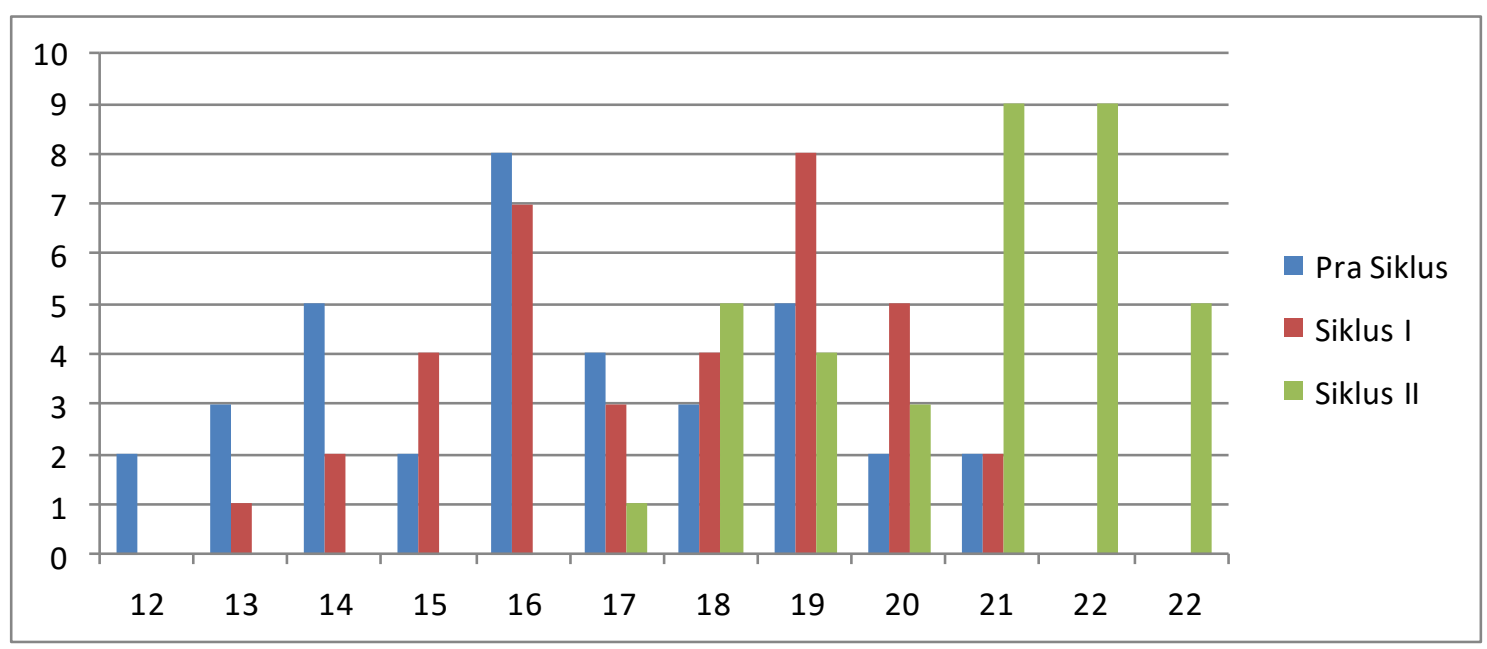

Gambar. 3.Grafik Batang Hasil Observasi PKJ Jumlah Nilai Yang Diperoleh

Tabel. 2. Hasil Analisis Deskriptif

\begin{tabular}{cccc}
\hline & Pra-Siklus & Siklus 1 & Siklus 2 \\
\hline rata-rata & 16.39 & 17.50 & 20.69 \\
std dev & 2.50 & 2.14 & 1.74 \\
modus & 16 & 19 & 22 \\
median & 16 & 18 & 21 \\
\hline
\end{tabular}

Hasil analisis deskriptif untuk data pra-siklus menunjukkan data berpusat pada skor 16 , pemusatan ini juga ditunjukkan dari ukuran median dan modus yang menunjukkan skor 16 , dengan standar deviasi sebesar 2.50 menunjukkan penyimpangan data pada pra-siklus sebesar 2.50 satuan, yang artinya menyebar paling banyak pada interval 13 sampai 19 . Pada siklus 1 data berpusat pada skor 17 namun kecenderungan skor adalah lebih tinggi dari pada 17, hasil yang sama juga ditunjukkan pada siklus 2 yaitu data berpusat pada skor 20 namun kecenderungan data memiliki skor yang lebih tinggi dari ukuran pemusatan datanya dengan standar deviasi yang semakin menurun mengambarkan data pada siklus 2 semakin seragam. Secara umum terlihat adanya tren dengan kecenderungan naik atau meningkat dari skor prasiklus ,siklus 1 dan siklus 2.

Tabel. 3. Rekapitulasi Data Ketuntasan

\begin{tabular}{llcccc}
\hline \multicolumn{2}{c}{ Persentase dan Kriteria Penilaian } & $\begin{array}{c}\text { Pra } \\
\text { Siklus }\end{array}$ & Siklus I & Siklus II & Ket \\
\hline $86 \%-100 \%$ & (Baik Sekali) & - & - & $14 / 38,9$ & Tuntas \\
$70 \%-85 \%$ & (Baik) & $14 / 38.9$ & $19 / 52.8$ & $21 / 58.3$ & \\
$55 \%-69 \%$ & (Cukup) & $17 / 47.2$ & $16 / 44.4$ & $1 / 2.8$ & Belum tuntas \\
Dibawah 55\% & (Kurang) & $5 / 13.9$ & $1 / 2.8$ & - & \\
Ketuntasan berdasarkan kriteria nilai & $14 / 38.9$ & $19 / 52.8$ & $35 / 97,2$ & \\
yng mencapai 70 \% ke atas & & 13.9 & 44.4 & \\
$\begin{array}{l}\text { Peningkatan dari } \\
\text { Siklus Ke Siklus }\end{array}$ & & & & \\
\hline
\end{tabular}


Pembahasan dengan diterapkannya pendekatan pada keterampilan proses bermain dalam pembelajaran pendidikan jasmani berbasis lesson study pada siswa kelas IV SD Negeri 2 Sesetan Denpasar Selatan, maka berdasarkan hasil analisis deskriptif secara umum terlihat adanya tren dengan kecenderungan naik atau meningkat dari skor pra-siklus, siklus1, dan siklus 2. Namun masih ada permasalahan yang masih perlu dicarikan jalan keluarnya adalah siswa yang masih kurang dalam pemahaman melakukan aktivitas fisik mempraktekkan kombinasi pola dasar gerak, gerak dasar lokomotor dan gerak keterampilan untuk membangun sebagai dasar penampilan dalam pengembangan gerak selanjutnya yang lebih baik perlu dicarikan jalan keluarnya dalam memperlihatkan kemampuan momentum dasar gerak, gerak dasar, dan gerak keterampilan terutama dalam gerakkan manipulasi melempar, menangkap dan memukul bola perlu ditingkatkan.

Pada siklus I hanya 19 orang siswa (52.8\%) dari 36 orang siswa yang telah mencapai nilai kriteria sama atau lebih besar dari kriteria yang ditentukan yakni $70 \%$ ke atas dengan ketuntasan klasikal ditetapkan $80 \%$, hal ini menunjukkan proses perbaikan pembelajaran yang dilakukan dalam mempraktekkan kombinasi pola gerak dasar lokomotor belum optimal. Beberapa siswa diantaranya masih kurang memahami gerakan yang seharusnya bisa dilakukan dan kurang konsentrasi, kurang serius sehingga dalam melakukan lempar dan tangkap bola kebanyakan siswa belum mampu menyesuaikan kekuatan yang dimiliki dalam melakukan lemparan bola kearah sasaran. Rudolf Laban (1930) mengemukakan bahwa gerakan yang diajarkan pada siswa sekolah dasar selalu berkaitan dengan waktu, beban, ruang, dan alur yang berkesinambungan yang mengalir dari satu gerak tertentu kegerak lainnya. Sesuai dengan pertumbuhan dan perkembangan pada siswa sekolah dasar baru menitik beratkan pada latihan yang sifatnya informal dan bebas karena mereka belum mampu menggunakan otot-otot besar maupun otot-otot kecil dengan baik secara silmutan.

Mengatasi kondisi seperti itu peneliti bersama tim mendiskusikan untuk mencarikan solusinya dan berupaya mengatasi dengan cara melakukan lempar tangkap menggunakan bola ekor dengan berbagai macam jenis dan ukuran. Demikian pula pada gerakan melempar dengan sasaran yang telah ditentukan dapat dilakukan menggunakan bola berbagai macam jenis dan ukuran dengan jarak diatur berbeda. Observer dalam melakukan tugasnya agar lebih mencermati momentum gerak yang dilakukan oleh siswa dalam mempraktekkan kombinasi pola gerak dasar lokomotor dengan berbagai variasi dan kombinasinya.

Pada hasil observasi dan refleksi siklus I, kendala yang dihadapi peneliti siswa masih kesulitan dalam melakukan gerakan memukul, lari dan lompat pada waktu permainan bola kecil, bola yang dipukul kadang-kadang jauh kebelakang bahkan kadang-kadang tidak sampai pada sasaran yang dituju. Kebanyakan siswa kurang percaya diri, berinisiatif dan tidak berani mengambil keputusan untuk menjemput bola, sementara ada siswa lainnya lebih semangat mengikuti pembelajaran yang disampaikan oleh gurunya. Jadi berdasarkan hasil refleksi bersama tim observer ketuntasan secara klasikal yang dicapai pada siklus I mencapai $52.8 \%$ belum memenuhi kriteria keberhasilan yang telah ditetapkan, untuk membuktikan lebih lanjut perbaikan pembelajaran diberikan pada siklus berikutnya.

Pada pelaksanaan perbaikan pembelajaran siklus II lebih mencermati dan mempraktekkan variasi dan kombinasi pola gerak dasar lokomotor, non lokomotor dan manipulatif, melalui bentuk-bentuk aktivitas pengembangan gerak dasar dan gerak keterampilan difokuskan pada gerak yang belum dikuasai seperti posisi tubuh dan ayunan lengan atas pada waktu lari, pergelangan tangan pada waktu gerakan memukul bola pada saat bermain kasti atau memukul sasaran balok, bowling game warna warni atau lingkaran yang dipasang pada dinding tembok yang telah ditentukan. Berdasarkan hasil perolehan observasi yang dilakukan observer, perolehan nilai siswa menunjukkan peningkatan nilai rata-rata kelas maupun peningkatan pada ketuntasan. Hasil observasi dan refleksi pada siklus 2 menunjukkan bahwa siswa dalam bermain sudah menunjukkan kerjasama yang baik dan rasa tanggung jawab tinggi dalam melaksanakan permainan kasti. Perubahan yang terlihat dalam mempraktekkan variasi dan kombinasi gerak melalui bermain guru lebih banyak memberikan 
peluang dan keleluasaan kepada siswa melaksanakan kegiatan praktek dan juga siswa memanfaatkan kesempatan ini secara baik dengan mengulangi dan kesempatan untuk mengembangkan gerakan-gerakan yang sudah pernah dipraktekkan. Hal ini tentu berdampak positif pada siswa dalam melaksanakan dan mempraktekkan variasi-variasi gerak yang dilakukannya dalam permainan kasti terkait dengan melakukan pola gerak dasar lokomotor, non lokomotor dan manipulasi.

Dengan demikian maka dalam batas-batas penelitian ini dapat disimpulkan bahwa efektifitas pendekatan keterampilan proses bermain dalam pembelajaran pendidikan jasmani berbasis lesson study dapat meningkatkan pengembangan kemampuan jasmani siswa kelas IV SD Negeri 2 Sesetan Denpasar Selatan.

\section{Simpulan dan Saran}

Berdasarkan hasil penelitian yang telah dilaksanakan maka dapat ditarik simpulan sebagai berikut.(1).Dapat meningkatkan kemampuan dasar gerak, gerak dasar dan gerak keterampilan siswa kelas IV SD Negeri 2 Sesetan Denpasar Selatan tahun ajaran 2017/2018. Berdasarkan data observasi yang dilakukan diperoleh hasil nilai rata-rata pada pra-siklus 16.39 dengan ketuntasan belajar $38.9 \%$, ini berarti yang telah mencapai nilai kriteria sama atau lebih besar dari kriteria yang ditentukan yakni $70 \%$ ke atas, belum mencapai ketuntasan $80 \%$ secara klasika (2).Pada siklus I hasil nilai rata-ratanya 17.50 dengan ketuntasan belajar 52.8 $\%$, ini berarti telah mencapai nilai kriteria sama atau lebih besar dari kriteria yang ditentukan yakni $70 \%$ ke atas, belum mencapai ketuntasan $80 \%$ (3).Pada siklus II hasil nilai rataratanya meningkat menjadi 20.69 dengan ketuntasan belajarnya sebesar $97.2 \%$ ini berarti telah mencapai nilai kriteria sama atau lebih besar dari kriteria yang ditentukan yakni $70 \% \mathrm{ke}$ atas, telah memenuhi atau mencapai kriteria ketuntasan yang ditetapkan $80 \%$ secara klasikal. Maka dengan demikian efektivitas pendekatan keterampilan proses bermain dalam pembelajaran pendidikan jasmani berbasis lesson study dapat meningkatkan pengembangan kemampuan jasmani siswa kelas IV SD Negeri 2 Sesetan Denpasar Selatan tahun ajaran $2017 / 2018$

Berdasarkan hasil penelitian yang dicapai pada pra-siklus, siklus I, dan siklus II menunjukkan bahwa dengan pendekatan keterampilan proses bermain dalam pembelajaran pendidikan jasmani berbasis lesson study ada kecenderungan mengalami peningkatan hasil perbaikan secara berkelanjutan.

Saran, bagi siswa (a). berdasarkan temuan penelitian, disarankan kepada siswa agar memanfaatkan kesempatan yang difasilitasi guru dengan mengikuti proses pembelajaran pendidikan jasmani olahraga dan kesehatan secara sungguh-sungguh dalam kegiatan proses pembelajaran yang berlangsung dengan menggunakan pendekatan saintifik berbasis lesson study. Bagi siswa yang tidak termotivasi tidak akan mau mengerjakan tugas-tugas oleh gurunya, akhirnya hasil belajar tidak optimal, sebaliknya siswa yang termotivasi akan menghabiskan waktu dan usahanya untuk melakukan tugas yang diberikan, siswa akan berlatih lebih serius sehingga mengarahkan kepada pembelajaran yang lebih efektive, lebihlebih lagi dalam konsep dasar gerak, gerak dasar, dan gerak keterampilan (b). mintalah siswa untuk mencoba menetapkan tujuan sendiri dalam apa yang sedang mereka pelajari, siswa yang diminta untuk menetapkan tujuannya sesuai dengan materi apa yang dibahas misalnya dalam pemahaman aktivitas fisik, mempraktekkan gerakan kombinasi pola gerak dasar, dasar gerak lokomotor (c). bagi siswa yang sudah dikondisikan mempraktekkan dasar gerak, gerak dasar, dan gerak keterampilan dengan baik, ibaratnya membangun sebuah rumah agar keindahan rumah itu tidak sia-sia maka fondasi rumah itu harus kuat dan kokoh adalah persyaratan yang semestinya merupakan hal yang paling penting. Bagi Guru $\quad$ (a). Guru hendaknya lebih kreatif dan inovatif untuk memberikan fasilitas berupa sumber belajar dan kesempatan yang lebih besar bagi siswa untuk membangun kemampuannya secara mandiri dan guru hendaknya dapat menerapkan berbagai macam strategi, model, pendekatan dalam 
pembelajaran untuk meningkatkan hasil belajar siswa (b). sebagai guru yang kreatif senantiasa melakukan inovasi dalam pembelajaran yang bersifat pengembangan, cegahlah dalam pemberian informasi yang terlalu banyak dan gunakan kalimat dan kata-kata yang sederhana (c).merancang sendiri maupun memodifikasi beberapa model dalam pembelajaran yang ternyata menyenangkan siswa, jauh lebih bermakna dalam pembelajaran, demikian pula dalam pemberian motivasi dan demonstrasi sangat penting (d). sebagai guru pendidikan jasmani olahraga dan kesehatan untuk meningkatkan pemahaman siswa dalam belajar dasar gerak, gerak dasar lokomotor dan non lokomotor, ketika akan merancang melaksanakan tugas di lapangan diharapkan selalu memikirkan program pengajaran seperti apa yang sesuai diberikan kepada siswa, metode apa yang harus dipilih, serta strategi apa yang harus diterapkan agar siswa dapat belajar dengan efektif. Bagi sekolah (a). berdasarkan pelaksanaan penelitian disarankan kepada kepala sekolah agar dapat menggunakan hasil penelitian ini sebagai pendukung sumber belajar guru dalam meningkatkan kualitas pembelajaran yang lebih baik dengan menciptakan pembelajaran yang menyenangkan di sekolah sehingga sekolah mampu menghasilkan siswa yang memiliki kemampuan yang berkualitas (b), sebaiknya sekolah mempertimbangkan penerapan pendekatan keterampilan proses bermain dalam pembelajaran pendidikan jasmani berbasis lesson study untuk meningkatkan pengembangan kemampuan jasmani. Bagi Peneliti Lain (a). Dari hasil pelaksanaan penelitian ini disarankan kepada peneliti lain agar dapat digunakan sebagai referansi untuk melaksanakan penelitian selanjutnya. Diharapkan kepada peneliti lain agar dapat mencari inovasi baru sebagai acuan untuk meningkatkan proses pembelajaran yang lebih baik (b). masih dipandang perlu untuk ditindak lanjuti guna mendapatkan informasi lebih lelngkap, terutamanya dalam mengembangkan alatalat yang dimodifikasi.

\section{Daftar Pustaka}

Agung, A.A.G. 2016. Statistika Dasar untuk Pendidikan. Yogyakarta : Deepublish Group CV Budi Utama

Agung, A.A.G. 1997. Pengantar Evaluasi Pengajaran. Singaraja : STKIP

Agung, A.A.G. 2003. Metodologi Penelitian. Singaraja: IKIP Negeri

Darsana. W. 2003. Efektivitas Pelaksanaan SKJ 2000 dan Senam Gong 2001 Terhadap Peningkatan Kesegaran Jasmani Pada Siswa SDN 2 Denpasar : Hasil Penelitian

Darsana. W. 2008. Penerapan Pendekatan Keterampilan Proses Bermain dalam Pembelajaran Pendidikan Jasmani untuk Meningkatkan Pengembangan Kemampuan Jasmani Siswa Kelas III SD Negeri 2 Sesetan. Denpasar : Hasil Penelitian

Depdiknas. 2005. Pedoman Penyusunan Usulan dan Laporan Penelitian Tindakan Kelas (Classroom Action Research). Jakarta : Dirjendikti Dit. PPTK Dan KPT.

Depdiknas. 2003. Kurikulum 2004 Sekolah Dasar dan Madrasah. Standar Kompetensi Mata Pelajaran Pendidikan Jasmani. Jakarta : Depdiknas.

Gabbard, Carl, Leblanc, Elizabeth, dan Lowi, Susan. 1987. Physical Education for Children. Prentice Hall, Inc : Englewood Cliffs.

Indradjati Sidi dan Ali Husein, HM. 2005. Dalam arahan Pendidikan dan Pelatihan Instruktur Tingkat Nasional Program Pembekalan Guru Kelas/Agama SD Dalam Mata Pelajaran Pendidikan Jasmani. Bogor : Depdiknas. 
Kantor Menpora. 1991. Sejarah Olahraga Indonesia. Jakarta : Kantor Mentri Negara Pemuda dan Olahraga.

Santyasa, I W. 2008. Metode Penelitian Tindakan Kelas, Pengembangan, Korelasional, Kausal Komparatif, dan Eksperimen. Makalah di sajikan dalam pelatihan bagi Dosen Universitas Pendidikan Ganesha Singaraja

Sudarsono. FX. 1996. Pelaksanaan Penelitian Tindakan Kelas (PTK). Depdikbud. Dirjen Dikti.

Sugiyanto, Agus Mahendra, dan Toto Subroto. 2005. Dasar-Dasar Belajar Gerak. Program Pengendalian dan Peningkatan Mutu Guru Penjas. Bogor : Depdiknas Dirjen Dikdasmen Ditendik.

Syamsir Aziz. 2005. Pembelajaran Permainan Kecil. Jakarta : Depdiknas Dirjen Dikdas men Ditendik.

Syarifuddin dan Yusuf.1996. IImu Kepelatihan Dasar. Jakarta: Departemen Pendidikan dan Kebudayaan Direktorat Jenderal Pendidikan Tinggi Proyek Pembinaan Tenaga Akademik.

Toho Cholik. 2000. Penelitian Aksi Dalam Proses Prestasi Proses Pelatihan Olahraga Surabaya : KONI Pusat 